\title{
Assessment of the effectiveness of a home-based care program for patients coinfected with tuberculosis and human immunodeficiency virus after discharge from a reference hospital in South-Eastern Brazil
}

\section{Authors}

Carlos Alessandro Plá Bento ${ }^{1}$

Enio Roberto Pietra Pedroso $^{2}$

${ }^{1}$ Master's Degree in Tropical Medicine at Health Science's(Infectology and Tropical Medicine) Postgraduate Course by the Medicine School of Universidade Federal de Minas Gerais.

Hospital Eduardo de Menezes (HEM) -

Fundação Hospitalar do Estado de Minas Gerais (FHEMIG), Belo-

Horizonte, MG, Brazil. ${ }^{2}$ Full Professor at Departamento de Clínica Médica of the Medicine School of Universidade Federal de Minas Gerais Centro de Pós-Graduação em Medicina Tropical da Faculdade de Medicina da Universidade Federal de Minas Gerais (FM-UFMG) Belo-Horizonte, MG, Brazil

Submitted on: 03/03/2010 Approved on: 06/29/2010

\section{Correspondence to: Carlos Alessandro Plá Bento \\ Hospital Eduardo de Menezes, Rua Dr. Cristiano Resende, 2213 Bonsucesso, 30622-020 Belo Horizonte, MG, Brazil. \\ Fax: 553133285029 \\ E-mail:}

plabento@uol.com.br

We declare no conflict of interest.

\begin{abstract}
The effectiveness of tuberculosis treatment delivered by a home-based care program to patients coinfected with HIV was compared with that of a service provided by outpatient departments. A retrospective study was made of a cohort of coinfected patients discharged from hospital between January 1998 and December 2002 who had been followed-up for one year within one of these programs. Two-hundred-and-forty-three patients who met the inclusion criteria were grouped according to their treatment program (group 1 received home-based care; group 2 attended outpatient departments) and then paired one-to-one across the groups by gender, age and level of education. Only 48 patients from each group could be paired. Apart from the duration of HIV infection, there were no statistically significant differences $(P<0.05)$ between patients in the two groups with respect to social-demographic status and clinical or laboratory characteristics. In group 1, 75.0\% of patients attained successful tuberculosis treatment compared with $72.9 \%$ of those in group $2(P=0.816)$. Treatment was abandoned by $22.9 \%$ of patients in group 1 and by $54.2 \%$ of those in group $2(P=0.008)$. The death rate within one year after discharge was $20.8 \%$ for group 1 compared with $6.3 \%$ for group 2 $(P=0.334)$. Although both programs achieved a similar success rate in the treatment of tuberculosis, patients receiving outpatient care were three to eight-times more likely to abandon the program. The importance of assigning patients at-risk of abandoning treatment to a home-based care program after discharge from hospital is emphasized.
\end{abstract}

Keywords: AIDS; tuberculosis; treatment outcome; adherence to treatment; home-based care.

[Braz J Infect Dis 2010;14(6):594-600] CElsevier Editora Ltda.

\section{INTRODUCTION}

Tuberculosis (TB) is one of the most important complications of HIV infection ${ }^{1}$ and requires multi-drug therapy over an extended period. Consequently, for both infections, close adherence to the treatment regime and careful monitoring of drug resistance are critical program issues. ${ }^{2}$ The successful treatment of TB requires appropriate medication as well as continuous supervision by medical staff including the direct observation of drug intake and monitoring of the disease throughout the treatment by bacteriological examination of the sputum. If all of these criteria are met, the control of $\mathrm{TB}$ is one of the most cost-effective health interventions. ${ }^{3}$ However, the number of TB cases is increasing worldwide, and the HIV pandemic is considered to be one of its major causes. ${ }^{4,5}$ In developed countries an increase in cases was due to coinfection with HIV, and paradoxically, the increase in longevity with the emergence of TB in the elderly. These groups have accumulated and caused cohabiting institutional outbreaks. Poorer countries, on the other end, kept and maintained high incidence rates increased in most of them between past and present decades. ${ }^{6}$ Among the intermediate countries, some have experienced a gradual reduction in the incidence of TB, as is the case of Brazil. ${ }^{7,8} \mathrm{~TB}$ is known to accelerate the progression of HIV and is associated with decreased survival. ${ }^{9}$ Moreover, TB and HIV have a number of characteristics in common and there is a clear requirement for an evidence-based international strategy to combat both diseases. ${ }^{10}$

In Brazil, at least 100,000 individuals are coinfected with TB/HIV. Whilst the intro- 
duction of highly active antiretroviral therapy (HAART) has resulted in a significant therapeutic breakthrough in the treatment of HIV-patients, non-adherence to the prescribed regime remains a formidable barrier to the success of the treatment, ${ }^{11,12}$ and innovative approaches are required in order to increase access and adherence to HAART, particularly amongst problematic sectors of the community. ${ }^{12-14}$ Since 1995 , the Ministry of Health in Brazil has guaranteed the availability of HAART for all citizens suffering from AIDS by the establishment of a comprehensive national program referred to as the Programa de Alternativas Assistenciais. ${ }^{15}$ This program encompasses both specialized assistance service (Serviços de Atendimento Especializado; SAE) that is delivered by outpatient departments of hospitals, and home therapy assistance (Assistência Domiciliar Terapêutica; ADT), the home-based care service of which is provided by interdisciplinary teams.

Clearly, the access of HIV-patients to HAART is essential in order to reduce the incidence of HIV-related TB. ${ }^{16}$ However, very few reports have compared the effectiveness of the intervention provided by the ADT program with that of self-administered treatment supervised by SAE in the follow-up of coinfected TB/HIV patients, especially those recently discharged from hospital. ${ }^{9,17}$ In order to compare the two programs, the success rate of TB treatment and the adherence to tuberculostatic and antiretroviral therapies of patients diagnosed with TB/HIV were monitored over a period of one year following their discharge from a hospital in Belo Horizonte (MG, Brazil) specializing in infectious and parasitic diseases.

\section{METHODS}

\section{Study design}

Details of the study were presented and approved by the Ethical Committee of UFMG and Hospital Eduardo de Menezes. A retrospective study of a cohort of HIV-diagnosed patients ${ }^{18}$ that were treated for TB in the Hospital Eduardo de Menezes - Fundação Hospitalar do Estado de Minas Gerais (HEM-FHEMIG) during the period from January 1st, 1998 to December 31st, 2002 was conducted using the hospital records as reference materials. Patients were followed up for one year after their discharge from hospital except when a subject abandoned the program or died during the period.

\section{Study population}

HIV-diagnosed patients were classified into two groups: group 1 consisted of patients who were followed up by the ADT program organized by HEM-FHEMIG imme- diately after their discharge, whilst group 2 included patients who were followed up by the SAE program organized either by HEM-FHEMIG or by the Centro de Referência e Treinamento em Doenças Infecciosas e Parasitárias Orestes Diniz (Prefeitura Municipal de Belo Horizonte and Hospital das Clinicas da Universidade Federal de Minas Gerais). Within each group, all patients older than 18 years, of both gender, and living in the metropolitan area of Belo Horizonte were initially included in the study. Patients who had left the hospital against medical advice, patients who had not engaged in one of the two care programs indicated above, patients who had returned to the hospital within seven days of their formal discharge, patients who had been transferred to other medical centers, and patients who had disappeared were excluded from the study.

A total of 240 patients were initially included in the study. The 57 patients comprising group 1 had been followed up by ADT for a variable length of time, according to the protocol adopted by the team, and were eventually transferred to one of the SAE programs. Patients received weekly home visits of up to three members of an interdisciplinary team composed of physicians, nurses and aides, physical therapist, psychologist and social assistant. They earned their medications according to demand and control of use was done by counting the tablets allowing immediate assessment of adherence to therapy. A caregiver was selected and trained to give the medications and perform the care directed by the team.

The 183 patients forming group 2 had been followed up exclusively by one or both of the SAE programs. Patients in this group collected their medicines at one-to three-monthly intervals from an outpatient department and were examined by a consultant infectious diseases specialist at that time. The type of assistance delivered to the patients after their discharge had been defined according to appropriate medical criteria during their period of hospital confinement. On this occasion, each patient had been accompanied by a relative or a community member who had accepted the responsibility of looking after them and making sure that the medications were taken as recommended by the medical team.

\section{Selection of patients}

After all of the data pertaining to the patients in the study population had been recorded, patients in group 1 were paired with those in group 2 on a one-to-one basis with respect to gender, age ( \pm 5 years) and educational level (illiterate, primary school, secondary school or university degree). All three features should be fulfilled. Patients in group 1 who did not find perfect matches in group 2 were excluded. 


\section{Determination of treatment outcome}

At the conclusion of the follow-up period, patients were classified as having (I) adhered to the treatment, (II) abandoned the treatment, or (III) died (regardless of the cause of death). Patients were deemed to have adhered to the treatment if they continued their TB medication for more than $80 \%$ of the time previously specified and failed with the antiretroviral treatment for less than 30 days. Patients who had adhered to the treatment were deemed to have received a successful TB treatment if they completed the treatment regimen and achieved clinical recovery, ${ }^{19}$ or if they attained a cure of the disease (that is, two consecutive negative bacilloscopy tests and presenting clinical recovery).

\section{Statistical analysis}

All data were recorded using appropriate standardized forms. Statistical analyses were carried out using SPSS (SSPS Inc., Chicago, IL) version 11.0 software. Descriptive and univariate analyses employing the $\chi^{2}$ test and Fischer's exact test were used to detect statistically significant differences between categories. Continuous variables were tested by comparison of their mean values within a 95\% confidence interval. In order to perform multiple regression univariate analysis, all variables presenting $P<0.25$ were considered: differences were deemed significant at $P<0.05$.

\section{RESULTS}

Of the total 240 patients, 57 were included in group 1 and 183 patients in group 2. Adherence to treatment one year after hospital discharge was achieved in $50.9 \%$ of patients in group 1 and $53 \%$ of those in group 2. The abandonment of treatment one year after hospital discharge was developed by $28.1 \%$ of patients in group 1 and $42.1 \%$ of patients in group 2 with $\mathrm{p}=0.129$ with a relative risk (RR) of 0.65 confidence interval (CI) $95 \%$ from 0.37 to 1.13 . The death occurred in $21 \%$ of patients in group 1 and $4.9 \%$ of patients in group 2 . The completion of TB treatment was achieved by $73.7 \%$ of patients in group 1 versus $72.7 \%$ in group 2 with $\mathrm{p}=0.88295 \%$ CI from -0.14 to $0.12 .^{20}$

Only 48 patients from group 1, originally comprising 57 individuals, could be paired with patients of group 2, thus the total number of patients included in the study was 96. Other than the duration of HIV infection, there were no statistically significant differences between patients in groups 1 and 2 with respect to their social-demographic status or their clinical or laboratory characteristics at discharge from the hospital.

The average age of all patients was 34.8 years, $62.5 \%$ were males, $89.6 \%$ had attended school for 8 years maximum and $65.6 \%$ lived in the city of Belo Horizonte. Most of the patients were single (63.5\%) and in $47.9 \%$ of the cases HIV infection had resulted from sexual intercourse with men. The average duration of infection for patients of group 1 was 27.8 months (standard deviation $\{\mathrm{SD}\}=39.1$ months), whilst in group 2 the average was 18.1 months ( $\mathrm{SD}=33.7$ months), values that were significantly different at $P<0.001$ (Table 1 ). The average time of hospital confinement was 58.1 days for patients of group 1 and 48.2 days for those of group 2 .

Prior to the start of the therapeutic program, 40 patients $(83.3 \%)$ of group 1 presented an average T CD4+ lymphocyte count of 182.6 cells $/ \mathrm{mm}^{3}$ ( $\left.\mathrm{SD}=49.0\right)$, and 39 patients $(81.3 \%)$ of group 2 exhibited an average $\mathrm{T}$ CD4+ lymphocyte count of 151.0 cells $/ \mathrm{mm}^{3}(\mathrm{SD}=37.6)$. When the results were dichotomized with respect to the T CD4 lymphocyte count level of 200 cells $/ \mathrm{mm}^{3}, 68.3 \%$ of group 1 and $45.5 \%$ of group 2 have shown values below this level, a difference between groups that was not significant $(P=0.678)$. The mean value of $\log _{10}$ (viral load) for patients in group 1 was 4.01 (equivalent to 10233 copies $/ \mathrm{mm}^{3}$ of viral RNA; SD = 1.52), whilst in group 2 the mean value was 4.52 (equivalent to 33,113 copies $/ \mathrm{mm}^{3}$ of viral RNA; SD $\left.=1.34\right)$. When the results were dichotomized with respect to the median baseline HIV level for $\log ^{10}$ (viral load) of 2.6 (equivalent to 400 copies $/ \mathrm{mm}^{3}$ of viral RNA), $26.5 \%$ of group 1 and $12.1 \%$ of group 2 presented values below this level, a difference between groups that was not significant $(P=0.122)$.

The average incidence of opportunistic infection prior to entry into one of the scheduled therapy programs was 3.5 for group 1 and 3.0 for group 2. Mycobacteriosis was diagnosed definitely in $34.4 \%$ of the patients, and for the majority (63.6\%), the presence of Mycobacterium tuberculosis was confirmed. The lungs were the organs most frequently affected by the disease (47.9\%). The therapy regimens employed rifampicin, isoniazid and pirazinamide (scheme S1;57.3\%), or S1 reinforced with etambutol (scheme R-S1;25\%), or one of the regimens containing streptomycin (17.7\%).

Table 2 presents a comparison between groups 1 and 2 with respect to the treatment outcome for patients after one year of being discharged from hospital. In group 1, $56.3 \%$ of the patients adhered to the treatment, whilst in group 2 only $39.6 \%$ adhered to the treatment $(P=0.102)$. Moreover, $22.9 \%$ of group 1 patients abandoned the treatment during the year, whilst the percentage was much higher $(54.2 \%)$ in group 2 with $P=0.008$ and relative risk $(\mathrm{RR})=3.36$. The number of deaths during the follow-up period was $20.8 \%$ in group 1 but only $6.3 \%$ in group 2 $(P=0.334)$. The treatment for tuberculosis was successful in $75 \%$ of the patients of group 1 and in $72.9 \%$ of group $2(P=0.816)$. 
Table 1. Statistical comparison of the parameters, determined prior to discharge from hospital, of TB patients coinfected with HIV who were to be supported by either an ADT (group 1) or an SAE (group 2) program

\begin{tabular}{|c|c|}
\hline Initial parameters & $P$ value $^{a}$ \\
\hline Treatment schedule for TB prescribed for 6 months & 0.669 \\
\hline Treatment schedule for TB prescribed for 9 months & 0.668 \\
\hline Treatment schedule for TB prescribed for 12 months & 0.374 \\
\hline Site of TB infection: lungs & 0.414 \\
\hline Site of TB infection: miliary & 0.665 \\
\hline Site of TB infection: disseminated & 0.460 \\
\hline Site of TB infection: pleural & 0.064 \\
\hline Site of TB infection: lymph nodal & 0.653 \\
\hline Site of TB infection: central nervous system & $0.117^{\mathrm{b}}$ \\
\hline Site of TB infection: osteoarticular & 0.315 \\
\hline Site of TB infection: urinary tract & 0.315 \\
\hline Site of TB infection: others & 0.504 \\
\hline Source of infection: sexual intercourse with men & 0.290 \\
\hline Source of infection: sexual intercourse with women & 0.996 \\
\hline Source of infection: intravenous drug users & 0.916 \\
\hline Source of infection: receivers of blood products & 0.367 \\
\hline TB therapy employed: S1c & 0.149 \\
\hline TB therapy employed: R-S1 ${ }^{\mathrm{d}}$ & 0.157 \\
\hline TB therapy employed: scheme including streptomycin & 0.789 \\
\hline Definite diagnosis for Mycobacteriosis & 0.566 \\
\hline Definite diagnosis for Mycobacterium tuberculosis & $0.553^{\mathrm{b}}$ \\
\hline Period of HIV infection & $<0.001$ \\
\hline T CD4+ lymphocyte count $<200$ cells $/ \mathrm{mm}^{3}$ & 0.678 \\
\hline Viral load $<2.60 \log _{10}$ (equivalent to 400 copies of viral RNA) & 0.122 \\
\hline
\end{tabular}

aDetermined using the $\chi^{2}$ test unless otherwise indicated.

${ }^{b}$ Determined using Fisher's exact test.

'Treatment scheme S1: rifampicin, isoniazid and pirazinamide.

${ }^{\mathrm{d} A s}$ treatment scheme S1 but reinforced with etambutol.

Table 2. Statistical comparison of treatment outcome parameters, determined one year after discharge from hospital, of TB patients coinfected with HIV supported by either an ADT (group 1) or an SAE (group 2) program

\begin{tabular}{|l|l|}
\hline Treatment outcome parameters & $\boldsymbol{P}$ value \\
\hline Successful treatment of TB & 0.816 \\
\hline Death after discharge from the hospital & 0.334 \\
\hline $\begin{array}{l}\text { Abandonment of treatment in the period } 30 \text { days up to } \\
\text { 1 year after discharge from hospital }\end{array}$ & 0.008 (RR: 3.36$)$ \\
\hline Adherence to treatment up to one year after discharge from hospital & 0.102 \\
\hline Final T CD4+ lymphocyte count $<200$ cells $/ \mathrm{mm}^{3}$ & 0.112 \\
\hline Final viral load $<2.60 \log _{10}$ (equivalent to 400 copies of viral RNA) & 0.019 (RR: 4.25) \\
\hline
\end{tabular}

aDetermined using the $\chi^{2}$ test; RR, relative risk. 
Logistic regression analysis of the data (Table 3 ) indicated a significant association, within a $95 \%$ confidence interval, between abandonment of treatment and the program scheduled for group $2(P=0.042 ; \mathrm{RR}=8.09)$. The difference between the initial and the final mean values of the T CD4+ lymphocyte count for group 1 was 160.5 cells $/ \mathrm{mm}^{3}$ $(\mathrm{SD}=49.0)$ and for group 2 was 74.1 cells $/ \mathrm{mm}^{3}(\mathrm{SD}=37.6)$. When the results from the two groups were dichotomised with respect to 200 cells $/ \mathrm{mm}^{3}$, a $P$ value of 0.112 was obtained according to the $\chi^{2}$ test, indicating that the difference between the groups was not significant. The mean $\log _{10}$ (viral load) value determined one year after discharge from the hospital was reduced to 1.46 (equivalent to 29 copies of viral RNA) for group 1 patients compared with 0.73 (equivalent to five copies of viral RNA) for those in group 2, values that were not significantly different within the $95 \%$ confidence interval. However, when dichotomised with respect to the level of $\log _{10}$ (viral load) of 2.6 (equivalent to 400 copies of viral RNA) there was a significant correlation with the treatment program $(P=0.019)$ such that group 1 patients presented a 4.25 -fold greater likelihood of attaining a viral load of less than 400 copies $/ \mathrm{mm}^{3}$ of viral RNA compared with patients in group 2 .

\section{DISCUSSION}

The only significant differences that could be detected, prior to their discharge from hospital, between patients in the two groups was that those in group 1 had been infected with HIV for a longer period than those in group 2. This is in line with the tendency to treat those patients with more complex disorders in their own homes since, if HIV-therapy is not effectively delivered, the progression of the infection results in an increase in morbidity. ${ }^{21}$

There was no significant difference between the success rates of the TB therapy for patients treated under the ADT or the SAE program, and treatment outcome was similar to that established in an analogous survey conducted in São Paulo in which 74\% of HIV coinfected patients attained a cure and $18 \%$ abandoned the therapy during the prescribed period. ${ }^{22}$ The TB cure rate achieved by this study were higher than the rates obtained by other national surveys with patients coinfected with HIV who achieved TB cure rates below 58.8\%.23-25 However, the success rates recorded for both groups of patients in the present study were lower than those observed in previous studies ${ }^{26-32}$ of populations, containing varying percentages of HIV-infected patients, that had been treated under a directly observed therapy (DOT)

Table 3. Multivariate analysis of TB patients coinfected with HIV who were supported by either an ADT (group 1) or an SAE (group 2) program and who had abandoned therapy during a one year period after discharge from hospital

\begin{tabular}{|c|c|c|}
\hline Program & Variables $^{\mathrm{a}}$ & $P$ value ${ }^{b}$ \\
\hline \multirow[t]{7}{*}{ ADT } & Treatment schedule for TB prescribed for 12 months & 0.847 \\
\hline & Source of infection: use of intravenous drugs & 0.063 \\
\hline & TB therapy employed: $\mathrm{S} 1^{\mathrm{c}}$ & 0.616 \\
\hline & TB therapy employed: scheme including streptomycin & 0.877 \\
\hline & Definite diagnosis for Mycobacteriosis & 0.143 \\
\hline & Site of TB infection: lungs & 0.740 \\
\hline & Number of previous hospital confinements & 0.835 \\
\hline \multirow[t]{7}{*}{ SAE } & Treatment schedule for TB prescribed for 12 months & 0.045 (RR: 8.09) \\
\hline & Source of infection: sexual intercourse with women & 0.798 \\
\hline & Definite diagnosis for Mycobacteriosis & 0.108 \\
\hline & Number of previous hospital confinements & 0.086 \\
\hline & Duration of previous hospital confinements & 0.220 \\
\hline & Gender & 0.540 \\
\hline & Age & 0.574 \\
\hline
\end{tabular}

${ }^{a}$ Only variables presenting $P<0.25$ were considered in the analysis.

${ }^{\mathrm{b}} \mathrm{RR}$, relative risk.

'Treatment scheme S1: rifampicin, isoniazid and pirazinamide. 
program. Furthermore, the number of patients who attained a cure under either treatment program in the present survey did not reach the $85 \%$ standard set by the World Health Organization. ${ }^{10,33}$

Various studies have indicated that the success rate of TB therapy in patients coinfected with HIV is low not only because of a higher rate of morbidity amongst such patients, but also because the access to such groups is more difficult. ${ }^{17,27,34}$ Furthermore, there is copious evidence to suggest that TB can accelerate the progression of HIV infection and thus reduce the chances of survival., 35 In the present study, the rate of morbidity was higher amongst patients included in group 1 (20.8\%) compared to group $2(6.3 \%)$, although the difference was not statistically significant $(P=0.816)$. Interfering factors, such as the distribution of patients between the ADT and SAE programs, may have contributed to this result despite the similarity of the other parameters between the two groups. Since the study was of a retrospective nature, none of the parameters measured were under strict control.

Patients in the SAE program were, typically, three-times more likely to abandon their treatment than those in the ADT program. Moreover, amongst patients whose TB therapy was prolonged (i.e. $\mathrm{ca} .12$ months), those in group 2 were eighttimes more likely to abandon the treatment compared with their counterparts in group 1.

Within TB treatment, the necessary levels of adherence are significantly different from those demanded for adequate HIV-treatment, mainly because of the need to control the selection pressure of HIV-resistant strains. ${ }^{36}$ It is thus accepted that TB patients need to take at least $80 \%$ of the prescribed tuberculostatic drugs in order to attain a complete cure, ${ }^{19,34,36}$ whilst HIV-patients need to take at least 95\% of the antiretrovirals prescribed for an indefinite period. ${ }^{11,12,37,38}$ Since the proportion of patients presenting a final load of less than 400 copies $/ \mathrm{mm}^{3}$ of viral RNA was statistically superior in group 1 , it is clear that adherence to the antiretroviral treatment was observed by most of the patients included in the ADT program. Therefore, it is suggested that short term TB treatments (of 6 to 9 months) for patients coinfected with HIV can be followed-up by either ADT or SAE programs with comparable results. However, for TB treatments requiring longer periods of medication (ca. 12 months) and almost total adherence to the regime, the follow-up of HIV coinfected patients would be more appropriate if provided under a ADT program.

The TB treatment delivered by both ADT and SAE programs offered to HIV-patients needs to be improved in order for the success rate to be raised to the levels recommended by the World Health Organization. ${ }^{10}$ New strategies must be designed in order to reach the more problematic sectors of the community including, for example, the adoption of special techniques for drug addicts and much closer collaboration with community health carers. Such work must be undertaken in an integrated manner by interdisciplinary teams of home-carers and those from outpatient departments. ${ }^{39}$ TB patients, coinfected with HIV, for whom a long duration therapy is prescribed should preferably be assisted by an ADT program. In further considerations of ADT programs, other parameters that influence adherence to treatment must be considered, the treatment success rate and adherence must be constantly checked and compared with SAE and DOT programs, ${ }^{37}$ and the follow-up period of patients must be longer than one year in order to allow for the evaluation of possible fatigue to antiretroviral adherence. ${ }^{40}$

\section{ACKNOWLEDGMENTS}

The authors wish to thank the team of Assistência Domiciliar Terapêutica do Hospital Eduardo de Menezes, the members of staff of SAME/HEM, SAME HC-UFMG and CTR Orestes Diniz, Aleida Nazareth for helping with the statistical analysis and the team of Editione - Editoração e Consultoria Cientifica S/C Ltda for editorial help.

\section{REFERENCES}

1. Secretaria de Assistência à Saúde. Programa Nacional de DST/ AIDS. Co-infecção TB/HIV/AIDS. Brasília: Ministério da Saúde, 1994. 20 p.

2. Farmer P, Leandre F, Mukherjee J, Gupta R, Tarter L, Kim JY. City-based treatment of advanced HIV disease: introducing DOT-HAART (directly observed therapy with highly active antiretroviral therapy). Bull World Health Org 2001; 79: 1145-51.

3. Pushpananthan S, Walley JD, Wright J. Tuberculosis in Swaziland: a health needs assessment in preparation for a community-based program. Trop Doctor 2000; 30: 216-20.

4. de Albuquerque MF, Albuquerque SC, Campelo AR et al. Radiographic features of pulmonary tuberculosis in patients infected by HIV: is there an objective indicator of co-infection? Rev Soc Bras Med Trop 2001; 34: 369-72.

5. Bleed D, Dye C, Raviglione MC. Dynamics and control of global tuberculosis epidemic. Curr Opinion Pulm Med 2000; 6: 74-9.

6. Chaisson RE, Martinson NA. Tuberculosis in Africa - Combating an HIV-Driven Crisis. N Engl J Med 2008; 358:1089-92.

7. Hijjar MA, Procópio MJ, Freitas LMR, Guedes R, Bethlem EP. Epidemiology of tuberculosis in the world, Brazil and Rio de Janeiro. Pulmão RJ 2005; 14 (4):310-14.

8. Bierrenbach AL, Gomes ABF, Noronha EF, de Souza MFM. Tuberculosis incidence and cure rates, Brazil, 2000-2004. Rev Saúde Pública 2007; 41 (supl.1):24-33.

10. World Health Organization. An expanded DOTS Framework for Effective tuberculosis control: Annex III TB/HIV. [http:// www.who.int/tb/dots/framework Accessed in 26th April 2005].

11. Ickovics JR, Cameron A, Zackin R et al. Consequences and determinants of adherence to antiretroviral medication: results from adult AIDS trial group protocol 370. Antiretroviral Ther 2002; 7: 185-93.

12. Stone VE. Strategies for optimizing adherence to highly active antiretroviral therapy: lessons from research and clinical practice. Clin Infect Dis 2001; 33: 865-72. 
13. Mitty JA, Flaningan T. Community-based interventions for marginalized populations. Clin Infect Dis 2004; 38: 373-5.

14. Mitty JA, Stone VE, Sands M, Macalino G, Flaningan T. Directly observed therapy for the treatment of people with human immunodeficiency virus infection: a work in progress. Clin Infect Dis 2002; 34: 984-90.

15. Manual de diretrizes técnicas para elaboração e implantação de programas de prevenção e assistência das DST/ AIDS no local de trabalho. Brasília: Ministério da Saúde, 1998. $213 \mathrm{p}$.

16. Corbett EL, Watt CJ, Walker $\mathrm{N}$ et al. The growing burden of tuberculosis: global trends and interactions with the HIV epidemic. Arch Int Med 2003; 163: 1009-21.

17. Miti S, Mfungwe V, Reijer P, Maher D. Integration of tuberculosis treatment in a community-based care program for persons living with HIV/AIDS in Ndola. Zambia. Int J Tuberculosis Lung Dis 2003; 7(Suppl 1): S92-8.

18. Diagnóstico sorológico da infecção pelo HIV. Portaria 488 de 17 de junho de 1998. Brasília: Ministério da saúde. [http://www.aids.gov.br. Accessed in 20th March 2001]. 19. Hill A.R., Manikal V.M., Riska P.F. Effectiveness of directly observed therapy (DOT) for tuberculosis: a review of multinational experience reported in 1990-2000. Medicine 2002; 81: 179-93.

20. Bento CAP. Estudo do papel da intervenção de serviço de Assistência Domiciliar para pacientes co-infectados por HIV/TB recém desospitalizados de hospital referência em Belo Horizonte - MG sobre a interrupção das terapias anti-retroviral e tuberculostática. Dissertação (Mestrado). 2006. UFMG. Faculdade de Medicina.

21. Palella Junior FJ, Delaney KM, Moorman AC et al. Declining morbidity and mortality among patients with advanced human immunodeficiency virus infection. New Eng J Med 1998; 338: 853-60.

22. Atomiya NA, Uip DE, Leite OH. Evaluation of disease patterns, treatment and prognosis of tuberculosis in AIDS patients. Braz J Infect Dis 2002; 6: 29-39.

23. Maruza M, Ximenes R, Lacerda H. Desfecho do tratamento e confirmação laboratorial do diagnostic de tuberculose em pacientes com HIV/AIDS no Recife, Pernambuco, Brasil. J Bras Pneumol. 2008; 34(6):394-403.

24. de Oliveira H, Marin-León L, Gardinali J. Análise do programa de controle da tuberculose em relação ao tratamento, em Campinas - SP. J Bras Pneumol 2005; 31(2):133-8.

25. Diniz L, Garrett D, Gerhardt G. Resultados do tratamento de tuberculose em capitais brasileiras - 2002. Bol Pneumol Sanit 2006; 14(2):71-84.

26. Kamolraratanakul P, Sawert H, Lertmaharit $S$ et al. Randomized trolled trial of directly observed treatment (DOT) for patients with pulmonary tuberculosis in Thailand. Trans Royal Soc Trop Med Hygiene 1999; 93: 552-7.
27. Rodger AJ, Toole M, Lalnuntluangi B, Muana V, Deutschmann P. DOTS-based tuberculosis treatment and control during civil conflict and HIV epidemic. Churachandpur District. India. Bull World Health Organ 2002; 80: 451-6.

28. China tuberculosis control collaboration. Results of directly observed short-course chemotherapy in 112.842 Chinese patients with smear-positive tuberculosis. Lancet 1996; 347: 358-62.

29. Maciel E, Silva A, Meireles W, Fiorotti K, Hadad D, Dietze R. Tratamento supervisionado em pacientes portadores de tuberculose utilizando supervisores domiciliares em Vitória, Brasil. J Bras Pneumol 2008; 34(7):506-13.

30. Gabardo B. Avaliação da Efetividade do tratamento supervisionado no controle da tuberculose pulmonar bacilífera em Curitiba - PR. Bol Pneumol Sanit 2006; 14(2):91-7.

31. Gazetta CE, Vendramini SHF, Ruffino-Netto A, Oliveira MRC, Villa TCS. Estudo descritivo sobre a implantação da estratégia de tratamento de curta duração diretamente observado controle da tuberculose em São José do Rio Preto e seus impactos (19982003). J Bras Pneumolol 2007; 33(2):192-8.

32. Falcão AB. Estudo comparativo do tratamento supervisionado da tuberculose com o auto-administrado. Bol Pneumolol Sanit 2006; $14(1): 21-5$.

33. World Health Organization Global Tuberculosis Program. Treatment of tuberculosis: guidelines for national programs. 2nd ed. WHO/TB/97.220. Geneva: World Health Organization, 1997.

34. Wobeser W, Yuan L, Naus M. Outcome of pulmonary tuberculosis treatment in the tertiary care setting-Toronto 1992/93. Tuberculosis treatment completion study group. CMAJ 1999; 160: 789-94.

35. Penerger TV, Sudre P, Lundgren JD, Hirschel B. Does the onset of tuberculosis in AIDS predict shorter survival? Results of a cohort study in 17 European countries over 13 years. AIDS in Europe Study Group. BMJ 1995; 311: 1468-71.

36. Liechty CA, Bangsberg DR. Doubts about DOT: Antiretroviral therapy for resource-poor countries. AIDS 2003; 17: 1383-7.

37. Altice FL, Mostashari F, Friedland GH. Trust and acceptance of and adherence to antiretroviral therapy. J Acquir Immune Defic Syndr 2001; 28: 47-58.

38. Peterson DL, Swindells S, Mohr J et al. Adherence to protease inhibitor therapy and outcomes in patients with HIV infection. Ann Intern Med 2000; 133: 21-30.

39. Harries AD, Hargreaves NJ, Chimzizi R, Salaniponi FM. Highly active antiretroviral therapy and tuberculosis control in Africa: synergies and potential. Bull World Health Organ 2002; 80: 464-9.

40. Bangsberg DR, Mundry LM, Tulsky JP. Expanding DOT tuberculosis to human immunodeficiency virus. Am J Med 2001; 110: 664-6. 